\title{
Edukacja Aleksandra i Mikołaja Pawłowiczów Romanowych
}

\begin{abstract}
The education of Alexander and Nicholas Pavlovich Romanov
This article concerns two very different ways and methods of bringing up two Russian tsars Alexander the First and Nicholas the First. Although they were brothers, one was born nearly twenty years before the second, and that influenced their future. Alexander, born in 1777, was the first son of the successor to the throne, and was raised from the beginning as a future ruler. The person who shaped his education most was his grandmother, empress Catherine the Second. She appointed the Swiss philosopher La Harpe as his teacher, and wanted Alexander to become an enlightened monarch. Nicholas, on the other hand, was never meant to rule and was never prepared for it. He was born in 1796 as the ninth child, and third son, and by the will of his parents, Tsar Paul I and Tsarina Maria Fyodorovna he received an education more suitable for a soldier than a tsar, but he eventually ascended to the throne after Alexander died. One may ask how these differences influenced them and how they shaped their personalities as people and as rulers.
\end{abstract}

Keywords: Romanov Children, Alexander I and Nicholas I, education, upbringing

Spośród dziesięciorga dzieci cara Pawła I i carycy Marii Fiodorowny dwóch synów - najstarszy Aleksander i drugi od końca Mikołaj zasiedli na rosyjskim tronie. Tych dwóch braci i dwóch władców wiele różniło - od charakterów począwszy, przez prowadzoną politykę, poglądy na temat miejsca Rosji w Europie, czy wreszcie okoliczności towarzyszących ich panowaniu. Pierwszy z nich wstąpił na tron, witany z nadzieją i radością, niemal niezauważalnie przyćmionymi jedynie dramatycznymi okolicznościami śmierci ojca, przeciwko drugiemu już pierwszego dnia jego rządów wybuchło w Petersburgu powstanie. Pierwszy dorobił się za życia chwały pogromcy Napoleona i zmarł w jej blasku, drugi pod koniec życia wplątał Rosję w klęskę wojny krymskiej. Pierwszy nadał konstytucję Królestwu Kongresowemu i zwłaszcza w początkach rządów cieszył się opinią liberała, drugi ową konstytucję odebrał, podczas panowania zaś systematycz- 
nie zwalczał wszelkie przejawy liberalizmu. Pierwszy wreszcie urodził się do władzy i od najmłodszych lat był do tego zadania sumiennie przygotowywany pod okiem swojej babki, Katarzyny II, drugi został carem niespodziewanie, do jego zaś wychowywania i kształcenia przykładano się siłą rzeczy mniej.

Celem niniejszych rozważań jest porównanie i skontrastowanie sposobów wychowania oraz charakteru edukacji, jaką w dzieciństwie i młodości odebrali Aleksander I i Mikołaj I, a także próba stwierdzenia, czy i w jakim stopniu mogły one wpłynąć na ukształtowanie się ich osobowości i odmiennych stylów rządów.

Aleksander I urodził się w grudniu 1777 r. jako pierwsze dziecko carewicza Pawła i jego drugiej żony, księżniczki Zofii Wirtemberskiej, która po ślubie i konwersji przyjęła imię Marii Fiodorowny, co za tym zaś idzie - jako pierwszy wnuk carycy Katarzyny II.

Można zadać sobie pytanie, ile w dynastii płynęło wówczas rosyjskiej krwi i odpowiedź brzmiałaby zapewne - raczej niewiele. Po kądzieli ani kropli. Po mieczu zaś cofnąc trzeba by się o trzy generacje, do prababki Aleksandra, babki Pawła i matki jego ojca Piotra Fiodorowicza, czyli do Anny Romanowej, córki Piotra Wielkiego, która w 1725 r. poślubiła księcia Hollstein-Gottorp. Męska linia Romanowych wygasła w 1730 r. wraz ze śmiercią piętnastoletniego Piotra II i od tego czasu, aż do roku 1796 Imperium Rosyjskim rządziły w zasadzie kobiety. Już wcześniej, po śmierci Piotra Wielkiego władzę przejęła jego żona Katarzyna I, córka łotewskiego chłopa. Po śmierci młodego Piotra II na tronie zasiadła córka Iwana V Anna, która wyznaczyła następcę po kądzieli spokrewnionego z Romanowymi. Iwan VI w chwili koronacji miał zaledwie kilka miesięcy i nie minął rok, nim został władzy pozbawiony i uwięziony - w więzieniu spędził później resztę życia i w wieku dwudziestu czterech lat zginął z rąk strażników. Władzę przejęła wówczas Elżbieta Piotrowna, druga córka Piotra Wielkiego i jej panowanie trwało dwadzieścia jeden lat. Elżbieta nie wyszła za mąż, przynajmniej nie oficjalnie, bowiem wśród sieci plotek i pogłosek oplatającej szczelnie większość aspektów prywatnego życia wszystkich carów pojawiła się również i teoria, że w tajemnicy poślubiła swojego kochanka Aleksego Razumowskiego ${ }^{1}$. To, jak również kwestia ich ewentualnego potomstwa, która pojawiła się zresztą w barwnej historii tak zwanej księżniczki Tarakanowej, pozostają nierozstrzygnięte ${ }^{2}$. Nie mając oficjalnego potomstwa, Elżbieta na następcę wyznaczyła swojego siostrzeńca, syna swej siostry Anny, księcia Holsztynu, który został w 1762 r. carem Piotrem III. Jego panowanie trwało od zimy do lata tego samego roku, został bowiem obalony na drodze zamachu stanu przez swoją małżonkę, Zofię Anhalt -Zerbst, znaną lepiej jako caryca Katarzyna II, albo Katarzyna Wielka. W polskiej histo-

\footnotetext{
${ }^{1}$ Informacje o tym ślubie por. m.in. w: A. Andrusiewicz, Romanowowie. Imperium i familia, Kraków 2014, s. 257-258.

2 W połowie lat 70. XVIII w. w Livorno we Włoszech pojawiła się młoda kobieta, podająca się za Elżbietę, wnuczkę Piotra Wielkiego, córkę carycy Elżbiety I i Aleksego Razumowskiego, prawną dziedziczkę rosyjskiego tronu. Znalazła posłuch i poparcie w pewnych warstwach, m.in. jej roszczenia gotowy był wesprzeć polski szlachcic, konfederat barski Karol Radziwiłł. Na zlecenie Katarzyny zbliżył się do niej graf Aleksy Orłow, uwiódł ją i zwabił na rosyjski okręt, gdzie została ujęta, przewieziona do Petersburga i osadzona w twierdzy Pietropawłowskiej. Zmarła tam kilka lat później. Historia „księżniczki” i Orłowa stała się inspiracją dla wielu romantycznych historii, z których można wspomnieć na przykład rosyjski musical Граф Орлов. O księżniczce Tarakanowej por. S.S. Montefiore, Katarzyna Wielka i Potiomkin, Warszawa 2013, s. 175-178.
} 
riografii owa władczyni, ze względów oczywistych i wiadomych, nie cieszy się specjalnym uznaniem ani też sympatią, jednak nie można powiedzieć, aby nie zasługiwała na przydomek Wielka. Odnosiła wymierne sukcesy w polityce zagranicznej, czy to prowadząc wojny z Turcją, czy też zyskując wraz z ziemiami polskimi dla Rosji okno na zachód, przeprowadziła liczne reformy. Za jej panowania Imperium było wewnętrznie stabilne, zaś z wszelkimi problemami, jak choćby powstanie Pugaczowa potrafiła sobie poradzić. Była monarchinią oświeconą - tak tylko, jak oświecony może być samodzierżawny władca Rosji, czyli w bardzo specyficzny sposób, abstrahując jednak od oświeceniowej praktyki, interesowała ją z pewnością oświeceniowa teoria ${ }^{3}$.

Paweł był jedynym dzieckiem Piotra i Katarzyny i, co za tym idzie, oczywistym następcą tronu. Stosunki matki z synem były jednak bardzo napięte, oboje nie mieli o sobie wzajem najlepszego mniemania. Katarzyna otwarcie miała głosić niezdatność syna do tronu ${ }^{4}$, on zaś uważał ją za uzurpatorkę. Paweł nie mógł bardziej różnić się od matki, zainteresowany był głównie, a pasję tę odziedziczył po ojcu i przekazał później wszystkim swoim synom, wojskiem i wojskowymi paradami w pruskim duchu, a wszystko, co choćby zahaczało o myśl oświeceniową wydawało mu się z gruntu podejrzane. Był wybuchowy i nieobliczalny do tego stopnia, że nie od rzeczy należałoby podejrzewać u niego jakąś chorobę psychiczną. Czterdzieści dwa lata czekał na tron i nim jego matka zmarła, większość czasu spędzał na swoistym wygnaniu w oddalonej o 45 kilometrów od stolicy Gatczynie, gdzie zabawiał się ulubionymi musztrami i defiladami5

Jego pierwsza żona, Natalia Aleksiejewna, zmarła w 1776 r., roniąc nienarodzonego syna. Paweł kochał ją i ciężko przeżył jej stratę, jednak z woli matki rychło poślubił wirtemberską księżniczkę. Między nim a drugą żoną z początku wszystko układało się dobrze, a i później, jak można przypuścić, istniała między nimi, aż do końca pewnego rodzaju więź. Doczekali się dziesięciorga dzieci i zażegnali wiszący nad dynastią od półwiecza kryzys.

Ani Paweł, ani Maria nie mieli większego udziału w wychowaniu swojego pierworodnego syna. Kiedy Aleksander przyszedł na świat, opiekę nad nim przejęła babka, idąc zresztą za przykładem, niegdyś, boleśnie zapewne, danym jej przez carycę Elżbietę która również odebrała młodej matce jej dziecko. Tak jak tamta decyzja wpłynęła zapewne znacząco na relacje Katarzyny i Pawła, tak i w tym przypadku Aleksander miał fatalne relacje z ojcem i nienajlepsze $\mathrm{z}$ matką. Zarówno on, jak i drugie w kolejności dziecko, jego młodszy brat Konstanty, byli wychowywani nie przez rodziców, ale babkę. To ona również im obu nadała imiona - Aleksandrowi na cześć Aleksandra Newskiego lub też Macedońskiego, Konstantemu jako przyszłemu władcy Konstantynopola ${ }^{6}$.

\footnotetext{
3 O panowaniu i osobie Katarzyny Wielkiej, patrz m.in.: A. Andrusiewicz, Romanowowie..., s. 270-320 (rozdział „Katarzyna II Aleksiejewna. Oświecony absolutyzm”).

4 Ibidem, s. 321.

${ }^{5}$ Więcej o życiu cara Pawła I: N. Ejdelman, Paweł I, czyli śmierć tyrana, tłum. W. i R. Śliwowscy, Warszawa 1990 .

${ }^{6}$ W. Bortnowski, Wielki Książe Konstanty i Joanna Grudzińska, Łódź 1961, s. 5.
} 


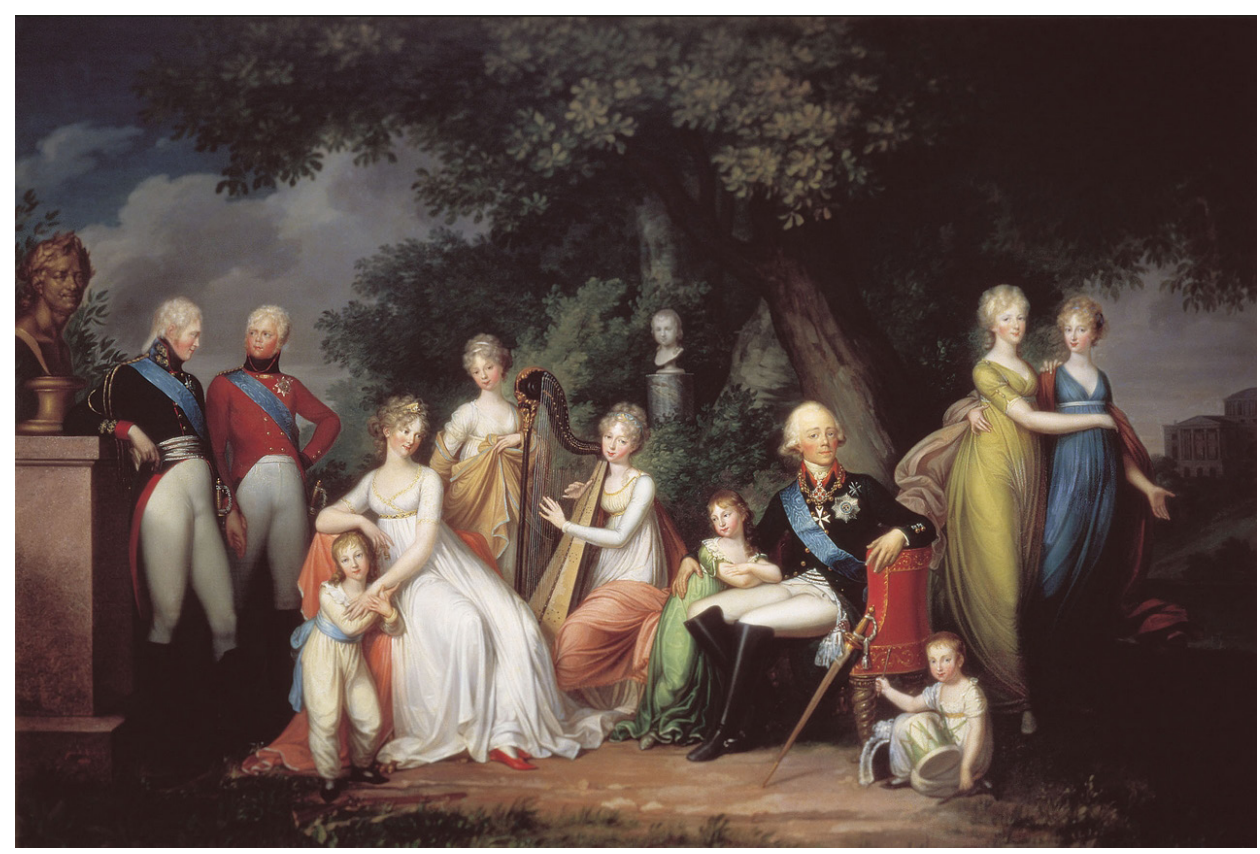

Ryc. 1. Gerhard von Kuegelgen, Portret Pawła I z rodzina, 1800 (https://commons.wikimedia. org/wiki/File:Family_of_Paul_I_of_Russia.jpg)

Katarzyna, zgodnie ze swoimi oświeceniowymi pasjami, zdecydowała się kształcić w tym duchu i Aleksandra. Miał on pewnego dnia stać się pierwszym carem-cesarzem wychowanym wedlug nowoczesnych wzorów i gwarantem realizacji linii politycznej bab$k i^{7}$. Oczywistym więc było, że sama caryca, nie zaś jej nieudany syn, czy jego młodziutka żona winna jest dopilnować wychowania dziecka. Można stwierdzić, że Katarzyna na wnuka przelała wszystkie te uczucia i nadzieje, których nie dane jej było ulokować w Pawle.

Na guwernera wnuków wyznaczyła Nikołaja Sałtykowa ${ }^{8}$, późniejszego generała-feldmarszałka Rosji - Aleksander miał wówczas sześć lat, Konstanty był o dwa lata młodszy. Wraz z nominacją, Katarzyna przygotowała dla Sałtykowa szczegółową instrukcję, w której zawarła swoją wizję wychowania wnuków ${ }^{9}$ - wizję, dla której zapewne inspira-

${ }^{7}$ A. Andrusiewicz, Aleksander I, Wielki gracz car Rosji - król Polski, Kraków 2015, s. 56.

8 А. Д. Аукштыкальните, Николай Иванович Салтыков и Фредерик Сезар де Лагарп, „Известия Саратовского университета”. Серия История, Международные отношения. 2017, т. 17, №1, стр. 28-34 https://cyberleninka.ru/article/v/nikolay-ivanovich-saltykov-i-frederik-sezar-de-lagarp (dostęp 18.08.2017).

9 Instructions composees par Catherine II pour la gouverne de Nicolai Ivanovitsch Soltykov w: G. Bridel, Le gouverneur d'un prince: Frederic Cesar de Laharpe et Alexandre I. de Russie. D'apres les manuserits inedits de F. C. de Laharpe et les sources russes les plus recentes, Lausanne 1902, s. 268-314. [https://archive. org/stream/legouverneurdunp00laha\#page/n5/mode/2up, dostęp 6.07.2017] 


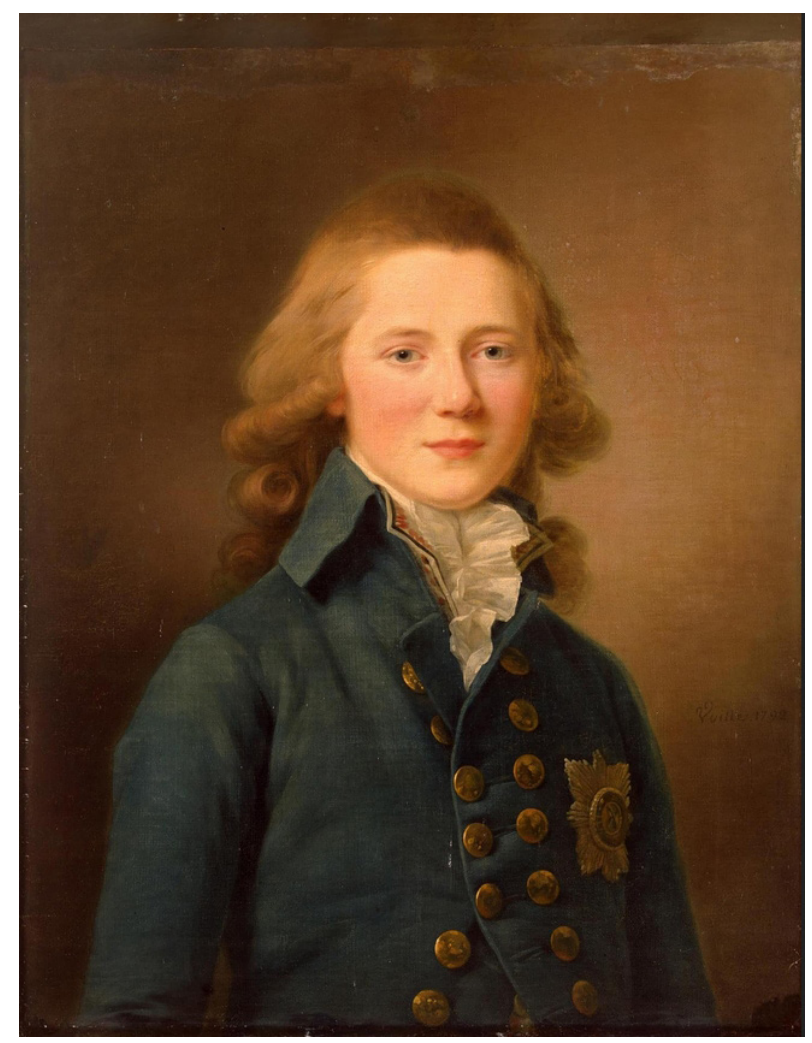

Ryc. 2. Jean-Louis Voille, Portret Wielkiego Księcia Aleksandra Pawłowicza, 1792 (https://commons.wikimedia.org/wiki/ File:Alexander_Pavlovich_of_Russia_by_J.-L.Voille_(1792, Hermitage).jpg)

cją w wielu aspektach było dzieło Jana Jakuba Rousseau Emil, czyli o wychowaniu. W instrukcji poruszone zostały sprawy związane z każdą chyba dziedziną życia dziecięcego, od kwestii ubioru małych Wielkich Książąt (stroje proste i z lekkich materiałów) ${ }^{10}$, przez ich żywność (również prosta, bez nadmiaru przypraw i soli, wino tylko na wyraźne zalecenie lekarskie, w lecie owoce sezonowe, między zaś posiłkami najwyżej kawałek chleba) ${ }^{11}$, sposób wietrzenia pokoi (wietrzyć regularnie, zimą za bardzo nie ogrzewać) ${ }^{12}$, czas snu (osiem, dziewięć godzin to długość odpowiednia dla chłopców w tym wieku) ${ }^{13}$,

10 Ibidem, s. 268.

11 Ibidem, s. 268-270.

12 Ibidem, s. 269.

13 Ibidem, s. 271. 
higienę (dbać o higienę, zimne kąpiele, koniecznie nauczyć chłopców pływać) ${ }^{14}$, aż po zalecane rozrywki (mają się dużo bawić i spędzać aktywnie czas, sami wybierać sobie zabawy - w granicach bezpieczeństwa i obyczajności - to bowiem jest dobrą miarą charakterów $)^{15}$. Prócz tego w chłopcach należało wyrabiać cnoty chrześcijańskie, silną wolę, posłuszeństwo wobec majestatu władzy, uprzejmość i dobre maniery. Dziecięcych łez nie wolno było tolerować, młodzi książęta mieli uczyć się do małego znosić ból i smutek cierpliwie i z godnością ${ }^{16}$. Prócz dbania o ciało i duszę, naturalnie w grę wchodziła również dbałość o młode umysły. Caryca zalecała, aby lekcje trwały najwyżej po pół godziny i kończyły się, zanim wychowankowie zdążyliby się znudzić17. Wśród przedmiotów, jakich mieli się uczyć, pojawiają się mało zaskakujące pozycje, wchodzące w, jeśli można tak rzec, stały repertuar wykształconego władcy tamtych czasów. Oczywiście, języki - Katarzyna zalecała jednak, aby nie zaniedbać pod żadnym pozorem również ojczystego języka rosyjskiego, zapewne nie chcąc, aby wnukowie zapomnieli go całkowicie. Radziła, aby naukę obcych języków połączyć z nauczaniem innych przedmiotów - chłopcy mieli więc uczyć się mineralogii po łacinie, botaniki po niemiecku, a zoologii po francu$\mathrm{sku}^{18}$. Poza tym w ich programie nauczania, rozpoczynającym się naturalnie od czytania, pisania, rysunków i arytmetyki, z czasem pojawić się miały przedmioty takie, jak geografia, astronomia i matematyka, prawo i historia - historia ogólna, antyczna, mitologia, genealogia etc ${ }^{19}$. Prócz tego zalecała uwzględnienie ćwiczeń fizycznych - jazdy konnej, pływania czy też szermierki ${ }^{20}$. Co interesujące, Katarzyna radziła, aby zrezygnować z poezji i muzyki, przedmioty te bowiem zajmowały nazbyt wiele czasu, nim osiągnie się w nich względną wprawę ${ }^{21}$.

Co do sposobu prowadzenia lekcji i implantowania wiedzy w młodych głowach, Katarzyna była wyraźnie zdania, że ma się to odbywać przez wzbudzanie w uczniach zainteresowania, nie zaś przez przymus. Stwierdziła wyraźnie, że strach nie uczy (la peur n'ensigne pas $^{22}$ ).

Prócz instrukcji dla guwernera caryca Katarzyna II spisała również skierowane do Aleksandra dziełko, zatytułowane „Бабушкина азбука великому князю Александру Павловичу"23. Stanowi ono coś w rodzaju zbioru ponad dwustu złotych myśli, jakie

14 Ibidem, s. 270.

15 Ibidem, s. 271-272.

16 Ibidem, s. 276.

17 Ibidem, s. 290.

18 Ibidem, s. 292-293.

19 Ibidem, s. 293-295.

20 Ibidem, s. 295.

21 Ibidem, s. 294.

22 Ibidem, s. 290.

${ }^{23}$ Inny przykład twórczości carycy stworzony z myślą o wnukach stanowią bajki dla wnuków opublikowane w XVIII w. W języku polskim wydane zostały w tomie Bajki carycy Katarzyny II dla wnuków i inne utwory baśniowe pisarzy rosyjskich XVIII wieku, Wrocław 2007. W zbiorze tym znajdują się dwie bajki autorstwa Katarzyny, napisana w 1781 r. Bajka o carewiczu Chlorze i druga z 1783 r. Bajka o carewiczu Fewieju. 
babka skierowała do wnuka. Pierwsza z nich brzmi - przed Bogiem wszyscy ludzie sa równi (перед Богом все люди равны ${ }^{24}$ ). Niektóre są dłuższe, jak opowiastki z morałem o perskim królewiczu Cyrusie, filozofach Diogenesie i Platonie czy greckim prawodawcy Solonie, inne zbudowane są na zasadzie krótkiego dialogu (pytanie: ile jest żywiołów? Odpowiedź: cztery: woda, ogień, powietrze, ziemia - na tej samej zasadzie padają też pytania o strony świata, kontynenty czy też ludzkie zmysły). Zbiór zamyka myśl przypisana imiennikowi adresata, Aleksandrowi Macedońskiemu - to rzecz królewska, czynić dobro $i$ znosić zło (то дело царское добро творить и злоречие терпеть). Łącznie „Бабушкина азбука” stanowi zestawienie myśli, mądrości i przestróg, które władczyni pragnęła przekazać swojemu ukochanemu wnukowi, którego tak chętnie widziałaby jako swojego bezpośredniego następcę.

Prawdopodobnie największe jednak piętno na wychowaniu i edukacji młodego Aleksandra odcisnął nauczyciel, którego caryca znalazła i wyznaczyła do tej funkcji, kiedy jej ukochany wnuk skończył dwanaście lat. Człowiek ten nazywał się Frederic-Cesar de La Harpe, pochodził ze Szwajcarii - urodzony w kwietniu 1754 r. w miejscowości Rolle, był synem byłego żołnierza i studiował filozofię w Genewie. Był z przekonania republikaninem o oświeceniowych poglądach. W Petersburgu zjawił się w $1783 \mathrm{r}^{25}$

O tym, jaki charakter miały nauki, jakie szwajcarski republikanin wszczepił przyszłemu carowi Rosji, wspominał m.in. w swoich pamiętnikach książę Adam Jerzy Czartoryski, młodzieńczy przyjaciel Aleksandra. Pisał on: pan de la Harpe był jedynym godnym wzmianki z pomiędzy tych, którym powierzono ksztatcenie W. ksiażat. Nie wiem komu poleciła Katarzyna ten wybór, przypuszczam, że musiat to być ktoś z zaprzyjaźnionych $z$ Grimmem lub Holbachem. Nie zdaje sie jednak, by pan de la Harpe przeprowadzit poważne studya z W. księciem w jakimkolwiek kierunku; potężnym bowiem wpływem jakiego używat na jego umyst i serce, byłby mógt wszystko z nim zrobić. W. ksiąze otrzymat od swego nauczyciela tylko powierzchowne wiadomości, ale mu wszczepit pan de la Harpe miłość ludzkości, sprawiedliwości, oraz wolności i równości dla wszystkich; nie dopuścił, by przesady, przykłady i podchlebstwa, przytlumity w nim te szlachetne sktonności. Natchnienie niemi i rozwinięcie ich u księcia rosyjskiego jest zastuga pana de la Harpe, $i$ to nie mata ${ }^{26}$.

Czartoryski wspomina również o innych odpowiedzialnych za kształcenie Wielkiego Księcia i wystawia im daleko mniej pochlebne opinie. O Sałtykowie pisze, że przyznać trzeba, że wcale nie był odpowiednim do kierowania wychowaniem przyszłego wladcy Rosyi $i$ wywierania nań zbawiennego wptywu ${ }^{27}$, o hrabim zaś Protazowie, innym z wychowawców Aleksandra - nie zaszkodzę mu, twierdząc, że byt skończonym głupcem, nie

\footnotetext{
${ }^{24}$ Ten i dalsze cytaty: Бабушкина азбука великому князю Александру Павловичу (http://dlib.rsl.ru/ viewer/01005436372\#?page=6), dostęp 6.07.2017.

25 G. Bridel, op. cit., Lausanne 1902, s. 7-17.

${ }^{26}$ Pamiętniki ks. Adama Czartoryskiego i korespondencya jego z cesarzem Aleksandrem I, tłum. K. Scipio, Kraków 1904, s. 81-82.

27 Ibidem, s. 82-83.
} 
mogacym być uszanowanym przez ucznia ${ }^{28}$. Nie lepiej wyrażał się również o jednym z wychowawców młodszego brata Aleksandra W. Ks. Konstanty oddany został hr. Sakenowi, którego stale wyśmiewat ${ }^{29}$.

Trudno powątpiewać w to, że właśnie La Harpe był tym z nauczycieli, który w największym stopniu wpłynął na edukację, charakter i poglądy Aleksandra ${ }^{30}$. Jak zostało już wspomniane, przybył on do Petersburga w 1783 r., niedługo później zaś caryca wyznaczyła go na głównego nauczyciela Aleksandra. Przekonała ją do tego zapewne krótka rozprawa, którą La Harpe skierował do Sałtykowa i w której przedstawił własny projekt programu nauczania dla Wielkich Książąt ${ }^{31}$. Proponował tam, że uczyć będzie swoich szlachetnie urodzonych podopiecznych nie tylko francuskiego, ale i geografii, historii i filozofii (aczkolwiek, jak zastrzega, raczej bez matematyki i fizyki), skreśla również krótko, w jakiej formie i jakiego charakteru byłyby to lekcje. Przy nauce języków, największy nacisk położyć zatem należałoby na ich użytkowanie. Nauka geografii powinna zacząć się od poznania Rosji, następnie zaś Europy i dalszych rejonów. Zwraca uwagę na szczególną rolę historii, zwłaszcza ważnej dla przyszłego władcy - każdy obywatel, który ma stać się użyteczny dla swojego kraju w sprawach publicznych musi studiować historię (Tout citoyen qui se destine à être utile à son pays dans le maniement des affaires publiques, doit étudier l'histoire ${ }^{32}$ ), pisze La Harpe i kontynuuje, stawiając swojemu uczniowi za przykład i przestrogę jego imiennika (On ne doit jamais oublier qu'Alexandre, né avec un beau génie et doué des qualités les plus brillantes, ne ravagea l'Asie et ne commit tant d'horreurs que pour avoir voulu imiter les héros d'Homère ${ }^{33}$ ). Historii antycznej zamierzał uczyć Aleksandra przez postaci takie, jak: Likurg, Solon, Katon, bracia Grakchowie, Cyceron i obaj Brutusowie. Poza tym, jak uważał La Harpe, ważne było również, aby Aleksander poznał historie poszczególnych państw, Rosji przede wszystkim, poza tym też historię niemiecką, duńską i szwedzką, a także - polską, której co prawda sam nie znał najlepiej, ale, jak podaje, nad którą pracuje właśnie niejaki pan Naruszewicz [...], mądry człowiek, znany ze swych dzieł wśród rodaków (M. Naruszevicz [...], homme d'esprit connu par des ouvrages estimés parmi ses compatriotes $\left.{ }^{34}\right)$. Jak można się domyślać, chodzi tu o Adama Naruszewicza i jego monumentalne dzieło $\mathrm{Hi}$ storia narodu polskiego. La Harpe wspomina również o History of England Davida Hu-

28 Ibidem.

${ }^{29}$ Ibidem.

${ }^{30}$ А. Ю. Андреев, Император и его учитель: личные и политические аспекты взаимоотношений Александра I и Ф.С. Лагарпа, „Филаретовский альманах” 8, 2012. С.76-97.

${ }^{31}$ Premier memoire remis le 10 juin 1784 au comte Soltykov, nomme gouverner en chef des jeunes Grands-Ducs, presente a S. M. I. Catherine II, avec ses ratures et apostille par elle, w. G. Bridel, op. cit., s. 235-267. [https://archive.org/stream/legouverneurdunp00laha\#page/n5/mode/2up, dostęp 6.07.2017]

32 Ibidem, s. 244.

33 Ibidem.

34 Ibidem, s. 252. 
me'a ${ }^{35}$, kilku francuskich autorach - w tym Monteskiuszu i o History of Philip II of Spain Roberta Watsona ${ }^{36}$.

$\mathrm{Na}$ instrukcji tej znajduje się uczyniony ręką carycy dopisek o treści ktokolwiek napisat to pismo, z pewnościa jest zdolny nauczać więcej, niż tylko języka francuskiego (celui qui a composé cet écrit paraît assurément capable d'enseigner plus que la seule langue française $^{37}$ ). Za jej aprobatą La Harpe został więc nauczycielem Aleksandra i wkrótce jednym z jego najbardziej zaufanych przyjaciół i powierników i, podążając za planem i wolą carycy, edukował go zgodnie z własnymi przekonaniami, oświeceniowymi, republikańskimi i egalitarnymi - co w przypadku przyszłego samodzierżawnego władcy Imperium Rosyjskiego samo w sobie wydawać się może i brzmieć paradoksalnie. Idee, które szwajcarski filozof wszczepił w chłonny umysł swojego wychowanka pozostały w nich długo i bez wątpienia stały się jednym z podstawowych elementów, budujących barwną, skomplikowaną i obfitującą w paradoksy tożsamość człowieka, który w przyszłości miał zostać nazwany Sfinksem Północy.

O przebiegu nauk Wielkich Książąt dowiadujemy się z zapisek La Harpe'a ${ }^{38}$. Rozpoczynają się one w 1786 r., przy czym notatki z każdego roku podzielone są na dwie części. W pierwszej ${ }^{39}$ omawia po kolei zakres przekazywanych młodzieńcom wiadomości z poszczególnych przedmiotów - nauki czytania, języka francuskiego, arytmetyki, geografii i historii. La Harpe podaje przykłady autorów, których książki czytał z chłopcami, zwraca również uwagę na odmienne uzdolnienia i podejście do nauki swoich dwóch wychowanków. O ile obaj Wielcy Książęta mieli wówczas jeszcze trudności z czytaniem, o tyle Aleksander, jeśli dostatecznie się skupił, jakoś sobie radził - jednym słowem, brakuje mu praktyki - zapisał La Harpe, za to Konstanty, żywszy i mniej uważny, musiał zastanawiać się nad każdym słowem. La Harpe uważał, że remedium na to stanowi nauka wierszy i prozy na pamięć - to miało pomóc opanować im w pełni alfabet w mowie i w piśmie. W drugiej części zapisek ${ }^{40}$ opisał starania i postępy chłopców, skupiając się bardziej na Aleksandrze. Rzadko można spotkać chłopców tak żywych, jak Wielcy Książęta, stwierdził, ani jednej minuty nie usiedza w miejscu ${ }^{41}$. Zapiski zawierają

35 David Hume był szkockim filozofem i historykiem, autorem traktatów filozoficznych. Historia Anglii to wydane w latach 1754-1761, sześciotomowe dzieło obejmujące czasy od Juliusza Cezara do Chwalebnej Rewolucji $1688 \mathrm{r}$.

${ }^{36}$ Robert Watson, szkocki uczony, wydał Historię Filipa II Hiszpańskiego w 1777 r. Zmarł, pracując nad dziełem poświęconym Filipowi III, dokończonym później przez Williama Thomsona.

37 Ibidem, s. 265.

38 Ф.Ц. Лагарп, Записки Лагарпа о воспитании в. к. Александра и Константина Павловичей 17861789 г2., “Русская старина”. Ежемесячное историческое издание. 1870 г. Том І. Санкт-Петербург, 1870, cтp. 152-204 http:/www.do1917.info/sites/default/files/user11/pdf/1870rysstarina1\%286\%29.pdf (dostęp 18.08.2017). Por. А. Ю. Андреев, «Записки» Ф.С. Лагарпа как источник по истории России конца XVIII - начала XIX в., “Вестник ПСТГУ” II. История. История Русской Православной Церкви. 2013. Вып. 4 (53). C.7-22, idem, Воспитание великих князей Александра и Константина Павловичей глазами Ф.-С. Лагарпа, „Филаретовский альманах” Вып.9, 2013. С. 90-122.

39 Ф.Ц. Лагарп, Записки..., s. 155 i n.

40 Ibidem, s. 163 i n.

${ }^{41}$ Ibidem, s. 168. 
szereg uwag dotyczących charakteru książąt i proponowanych przez nauczyciela sposobów postępowania z nimi w zależności od zachowania.

Edukacja Aleksandra skończyła się w 1793 r., wraz z jego ślubem z księżniczką badeńską Luizą, która przybrała w Rosji imię Elżbiety Aleksiejewny. Pan młody miał wówczas szesnaście lat, jego żona była dwa lata młodsza. Stanowili piękną parę, oboje młodzi, jasnowłosi i pełni uroku, przy tym zaś parę całkowicie niedobraną. Małżeństwo to skojarzyła oczywiście caryca Katarzyna, chcąca jak najprędzej ożenić wnuka i tym samym wzmocnić jego pozycję jako potencjalnego następcy tronu, z pominięciem swojego syna, a ojca Aleksandra. Wraz ze ślubem Aleksander stawał się oficjalnie pełnoletni. La Harpe opuścił Petersburg dwa lata później, pozostawiając swojemu wychowankowi instrukcję, zawierającą porady na dalszą drogę życia w czternastu punktach. Niektóre z nich dotyczyły spraw całkowicie codziennych - jak rada, aby Aleksander kładł się spać i wstawał wcześnie ${ }^{42}$, nie jadł nazbyt dużo ${ }^{43}$ i poświęcał rankami trochę czasu na samodzielną naukę $e^{44}$. Inne natomiast skierowane były już nie do młodzieńca, a do członka rodu panującego, do przyszłego władcy. La Harpe radził więc, aby Aleksander nie uzewnętrzniał złych emocji, zachowywał pobłażliwość dla niższych sobie ${ }^{45}$, interesował się losami ludzi z całej Rosji, nie tylko najbliższego otoczenia ${ }^{46}$, a także aby pielęgnował swoje więzi z żoną i bratem, ponieważ byli oni jedynymi ludźmi, na których mógł polegać w pełni i ufać bez zastrzeżeńn ${ }^{47}$. Instrukcję swoją La Harpe zakończył prośbą, aby Aleksander wspominał go czasem, aby kiedy spoglądać będzie na mapę Europy poświęcił myśl mieszkającemu nad Jeziorem Genewskim w Szwajcarii rolnikowi, którego wzrok zwraca się często ku Rosji i który nosi go w swoim sercu:

Relisez quelquefois ces derniers avis, Monseigneur, ce sont les adieux d'un homme qui eut onze ans l'honneur de vous être attaché par ses fonctions, et dont les veux les plus ardents sont pour votre bonheur. Lorsqu'en arcourant la carte de l'Europe vous distinguerez la Suisse, arrêtez un moment vos regards sur le lac de Genève, et daignez vous rappeler que sur ses rives, à Genthod, habite un cultivateur dont les yeux se tournent fréquemment vers la Russie, et qui vous porte dans son cour.

Accueillez, je vous prie, l'expression vraie des sentiments de mon dévouement éternel et du respect avec lequel j'ai l'honneur d'être Fr.- CÉSAR DE LA HARPE ${ }^{48}$.

Aleksander nie zapomniał bynajmniej o swoim nauczycielu. Pisał do niego listy, $\mathrm{w}$ których nazywał go swoim drogim i prawdziwym przyjacielem (mon cheri et vrai $\left.a m i^{49}\right)$, zaś kiedy w kilka lat później objął rosyjski tron, sprowadził La Harpe’a z powro-

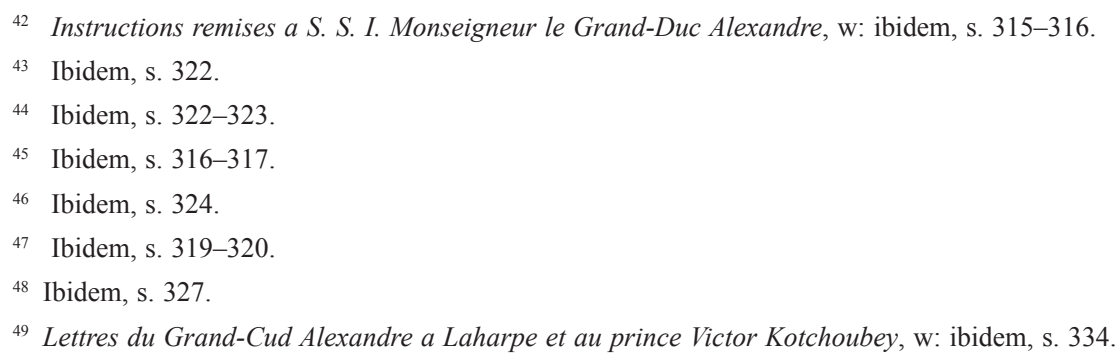


tem i mianował go, obok Czartoryskiego, Strogonowa, Nowosilcowa i Koczubeja, członkiem swojej tajnej rady. Jak podaje Czartoryski, La Harpe przybył do Petersburga w mundurze dyrektoriatu Republiki Helweckiej, której był jednym z założycieli ${ }^{50}$.

Funkcjonowanie owej tajnej rady związane było z początkami panowania Aleksandra I, dającym się podzielić na trzy zupełnie od siebie odmienne części. Pierwsza z nich to okres, w którym rozbrzmiewały hasła o reformach, o liberalizmie, o zmianach. Niedługo jednak, później młody car musiał zmierzyć się ze sprawami zgoła innymi, które skutecznie zaabsorbowały jego uwagę na co najmniej dekadę. Mowa tu naturalnie o wojnach, jakie Rosja, wraz z innymi państwami europejskimi, głównie Anglią, Austrią i Prusami toczyła przeciwko Napoleonowi Bonapartemu. O roli, jaką odegrała w nich Rosja, o osobistych stosunkach rosyjskiego cara z Cesarzem Francuzów napisano już wiele i jest to historia fascynująca i skomplikowana, pełna barwnych epizodów - na bitwie pod Austerlitz, z której pola walki Aleksander uciekał ze łzami począwszy, przez pokój zawarty na rzece Niemen, spotkanie w Erfurcie, nieudane plany matrymonialne Napoleona związane z Katarzyną, ukochaną młodsza siostrą Aleksandra I, po punkt kulminacyjny, który rozegrał się w 1812 r. na tle płonącej Moskwy i śnieżnej zawieruchy rosyjskiej zimy, po Lipsk i po Waterloo, i wreszcie po tańczący kongres, który zebrał się w Wiedniu w 1815 r. Z wojen napoleońskich Aleksander I wyszedł zwycięsko, w glorii i chwale pogromcy Napoleona i stał się jednym z budowniczych nowego ładu w Europie. System wiedeński okazał się, jak na tego rodzaju, odgórnie narzucony system, wyjątkowo trwały i w sumie przetrwał sto lat, aż do wybuchu Wielkiej Wojny w 1914 r., zbudowany został zaś na kilku zasadach, którym jednak łącznie przyświecał główny cel - zaprowadzić porządek, zburzony jeszcze przez rewolucję francuską i wszystko, co przyniosła, a także nie dopuścić do tego, aby coś podobnego się kiedykolwiek powtórzyło. Jego głównym autorem i twórcą był Klemens Metternich, genialny i utalentowany minister austriackiego cesarza, oprócz niego jednak wyróżnić należy przynajmniej dwie postaci - Charlesa-Maurice’a Talleyranda, który osobiście na drodze dyplomacji wyciągnął w Wiedniu Francję z roli przedmiotu do politycznego podmiotu i właśnie ,pogromcy Napoleona”, cara Aleksandra I ${ }^{51}$.

Aleksander I w 1815 r. skończył trzydzieści osiem lat i nie był już młodym władcą liberałem, którego wstąpienie na tron witano z nadzieją i radością. Lata panowania, prowadzone wojny i wreszcie wciąż zapewne żywa pamięć o okolicznościach śmierci jego ojca - o których kilka słów powiemy w dalszym ciągu artykułu - nadszarpnęły jego zdrowie, kondycję, rozchwiały bardziej jeszcze i tak chwiejny i zmienny charakter. Wychowanek oświeceniowego filozofa, Aleksander I zaczął coraz bardziej skłaniać się ku religii w jej najbardziej mistycznych przejawach, czego symbolem może być jego znajomość i kontakty z baronową Julianną von Krudener, mistyczką widzącą w nim wybawiciela przed mocami Napoleona Antychrysta. Podobno to za jej namową Aleksander I

\footnotetext{
50 Pamiętniki..., s. 173.

51 Więcej o Kongresie Wiedeńskim: D. King, Wiedeń 1814. Jak pogromcy Napoleona, bawiąc się, ustalili ksztalt Europy, tł. N. Radomski, Poznań 2009; więcej o udziale Aleksandra w napoleońskiej epopei np. A. Andrusiewicz, Aleksander I... .
} 
wpadł na koncepcję Świętego Przymierza ${ }^{52}$, koncepcję przedziwną z kilku co najmniej względów. Święte Przymierze w swych założeniach miało być sojuszem chrześcijańskich władców, zawiązanym w obronie przed rewolucyjnym neopogaństwem. Była to instytucja jednocześnie religijna i polityczna - na tym pierwszym aspekcie skupiał się Aleksander I, na drugim raczej już Metternich, a także zarówno reakcyjna, jak i ekumeniczna łączyła wszak braterskimi więzami prawosławnego cara, katolickiego cesarza Austrii i protestanckiego króla pruskiego. Z czasem Święte Przymierze zaczęło jednak oddalać się od założeń Aleksandra I, zwrot ten podyktowany był zaś narastającymi przez resztę wieku ruchami sprzeciwu wobec wiedeńskiego porząaku. Ruchy te dotarły także i do samej Rosji, kiedy jednak zaowocowały pod koniec 1825 r. powstaniem, to nie był już problem Aleksandra.

W tej powiedeńskiej, reakcyjnej Europie znalazło się jednak i miejsce dla państwa konstytucyjnego. Utworzenie jego było rozwiązaniem jednego z bardziej palących i kontrowersyjnych problemów kongresu. Po upadku Napoleona nastał kres krótkiej historii Księstwa Warszawskiego i zwycięzcy musieli zdecydować, co uczynić z ziemiami polskimi i Polakami. Na mocy ich decyzji powstało wówczas Królestwo Polskie, którego królem został Aleksander. Królestwo Polskie, zwane potocznie Kongresówką, było swoistym eksperymentem konstytucyjnym i osobistym poligonem doświadczalnym cara, który mógł tam testować swobodnie parlamentaryzm i konstytucję, zanim zdecydowałby się zaimplementować je również w Rosji. Z perspektywy czasu ocenić należy, że eksperyment ten nie wypalił. Przede wszystkim - tworzył paradoksalną i niewygodną sytuację, czyniąc z jednej osoby samodzierżawnego cara i konstytucyjnego króla.

Sama idea Kongresówki świadczy, że w Aleksandrze I wciąż tliły się myśli i marzenia o reformach, nie zostały jednak one zrealizowane. Ostatni etap jego rządów, ta dekada dzieląca Kongres Wiedeński od śmierci cara, kojarzona jest zazwyczaj z postacią hrabiego Aleksieja Arakczejewa, który w tamtym okresie stał się drugą po władcy osobą w państwie. Pod koniec życia na Aleksandra spadło wiele problemów i zawodów - począwszy od osobistej tragedii związanej ze śmiercią Zofii, jednej z nielicznych dzieci Aleksandara I, które przeżyły dzieciństwo, ukochanej córki jego i jego długoletniej kochanki Marii Naryszkiny, przez kłopoty dynastyczne i polityczne, niespełnione nadzieje i ambicje, a także, zapewne, wyrzuty sumienia. Zmarł w grudniu 1825 r. w Taganrogu.

Aleksander I był dziwnym człowiekiem o trudnym do uchwycenia charakterze. Jednym z paradoksów jego osobowości i rządów było zaś bez wątpienia wyraźne rozdarcie między reakcją a reformatorstwem, między religijnym mistycyzmem a oświeceniowym wychowaniem. Wydaje się, że edukacja, którą odebrał i atmosfera, którą od najmłodszych lat otoczyła go jego babka, znacząco wpłynęły na te właśnie cechy. Aleksander był autokratycznym władcą wychowanym w duchu oświeceniowym i ani jedna, ani druga z tych tożsamości nie opuściły go nigdy w pełni i powodowały wewnętrzne konflikty i wahania.

${ }^{52}$ O baronowej Krudener: A. Andrusiewicz, Aleksander I..., s. 416-430 (rozdział XXVIII Biaty aniol); A. Zamoyski, Święte szaleństwo. Romantycy, patrioci, rewolucjoniści 1776-1871, tłum. M. Ronikier, Kraków 2015, s. 274-275. 
Kiedy zmarł Aleksander, pozostawił po sobie problem sukcesyjny. Nie doczekał się żadnego syna z prawego łoża, a obie córki, które urodziła jego żona zmarły w dzieciństwie. Tron więc przejść musiał w ręce jego brata i zgodnie z prawem należał się Wielkiemu Księciu Konstantemu, drugiemu z synów Pawła i Marii. Konstanty jednak, z przyczyn, nad którymi nie będziemy się tu rozwodzić, zaznaczymy jedynie, że w grę wchodziła Kongresówka i morganatyczne małżeństwo, zrzekł się władzy ${ }^{53}$. Następcą Aleksandra został dopiero trzeci brat, Mikołaj.

Mikołaj Pawłowicz Romanow urodził się w 1796 r. Był trzecim synem oraz dziewiątym i przedostatnim dzieckiem Pawła i Marii. Był też ostatnim ich dzieckiem, które przyszło na świat jeszcze za życia swojej babki, carycy Katarzyny. Katarzyna zmarła wkrótce po jego narodzinach, uprzednio jednak zdążyła ucieszyć się kolejnym, trzecim już wnukiem. Wnuczki, których doczekała się sześciu cieszyły ją w mniejszym stopniu. Mały Mikołaj natychmiast stał się jej ulubieńcem. W listach do swojego korespondenta, Melchiora Grimma wróżyła mu z góry przyszłość jeszcze świetniejszą od starszych braci, pisząc że $w$ porównaniu z nim okaża się karłami ${ }^{54}$. Gdyby Katarzyna żyła choćby kilka lat dłużej, zapewne zadbałaby o jego edukację i wychowanie co najmniej równie starannie, jak zadbała niegdyś o Aleksandra. Jednak Mikołaj przyszedł na świat w czerw$\mathrm{cu}$, a już w listopadzie tego samego roku Katarzyna zmarła.

Jeśli planowała przed śmiercią jeszcze odsunąć od władzy syna i wyznaczyć swoim następcą Aleksandra, jeśli nawet sporządzone zostały już w tym celu jakieś dokumenty - jej zamiary umarły razem z nią. Po Katarzynie na carskim tronie zasiadł Paweł i rozpoczęło się jego krótkie, zaledwie pięcioletnie panowanie, które zakończyło się zimą 1801 r. w nader dramatycznych okolicznościach.

Najbardziej rzucającą się w oczy cechą charakterystyczną rządów Pawła było zapewne jego stanowcze odcięcie się od swojej matki i poprzedniczki, nie tyle może w sferze czysto politycznej, co symbolicznej. Pokazowo czcił pamięć swojego zamordowanego ojca, któremu urządził huczny, powtórny pochówek, składając razem w Twierdzy Pietropawłowskiej zwłoki obojga rodziców. Przez jakiś czas wydawało się również, że jego stosunki z Aleksandrem nie ulegną zaostrzeniu, syn złożył ojcu przysięgę wierności i był oczywistym jego następcą. Wciąż jednak istniało między nimi pewne napięcie, które zaczęło się pogłębiać, najpierw ukrytym nurtem, później zaś bardziej już widocznym i jawnym. Dochodziło do ostrych spięć - pewnego dnia na przykład Paweł wpadł do komnat syna, zastał go na lekturze zakazanych, ,wywrotowych” lektur i w gniewie polecił jego baczniejszej uwadze tragiczną historię carewicza Aleksego, skazanego na śmierć przez swojego ojca, Piotra Wielkiego ${ }^{55}$. W końcu wokół Aleksandra zaczęła gromadzić się opozycja przeciwko carowi. Ostatecznie też zawiązał się spisek. Jego głównym pomysłodawcą był hrabia Nikita Pietrowicz Panin, kierowany zapewne osobistą urazą wobec Pawła za niełaskę, w którą popadł w 1799 r. Zaangażowani w niego byli

\footnotetext{
53 Więcej o Konstantym: W. Bortnowski, op. cit.; E. Karnowicz, Wielki Książę Konstanty. Zarys biograficzny, Warszawa 1900.

${ }^{54}$ Za: W. B. Lincoln, op. cit., s. 44.

55 A. Andrusiewicz, Aleksander I..., s. 120.
} 
także niektórzy wyżsi oficerowie, a wraz z nimi Piotr Aleksiejewicz Pahlen, generał-gubernator Petersburga. To właśnie Pahlen wciągnął prawdopodobnie do spisku cesarzewicza Aleksandra, kładąc mu przed oczami, a to dobro Rosji, a to bezpieczeństwo osobiste. Spiskowcy ostatecznie wykonali swój plan. Pod koniec zimy 1801 r. w Zamku Michajłowskim car Paweł I zjadł wraz z rodziną swoją ostatnią kolację, po czym udał się na spoczynek do swoich apartamentów, do których przed północą wkroczyli spiskowcy. Najpierw zażądali od niego podpisania aktu abdykacji, kiedy zaś odmówił - zaatakowali go. Nie wiadomo do końca, czy Paweł zmarł od razów, napastnicy na wszelki wypadek udusili go jeszcze szarfą ${ }^{56}$.

Rola Aleksandra nie jest do końca jasna, można jednak stwierdzić ze sporą dozą prawdopodobieństwa, że jeśli nawet nie uczestniczył czynnie w spisku, był świadomy jego istnienia i do końca swoich dni żył w cieniu caro- i ojcobójstwa.

Jak widać, pierwsze lata życia Mikołaja obfitowały w wiele zdarzeń i problemów rodzinnych. Od jego narodzin, do piątych urodzin na tronie zasiadało trzech różnych władców, z których każdy miał inną koncepcję co do tego, jak powinno się kierować wychowaniem małego Wielkiego Księcia. Katarzyna, jak zostało już wspomniane, miała zbyt mało czasu, aby odcisnąć tu swoje piętno, pierwszym więc, który podjął początkowe decyzje dotyczące kształcenia Mikołaja i jego młodszego brata, urodzonego dwa lata później w 1798 r. Michała, jedynego porfirorodnego spośród całego rodzeństwa, był ich ojciec. Paweł podszedł do sprawy ze zgoła innej strony, niż miała to w zwyczaju czynić jego matka i zamiast szukać zachodnich filozofów i sporządzać własnoręcznie utrzymane w duchu oświeceniowym instrukcje, wyznaczył na opiekuna swoich najmłodszych synów niejakiego Matwieja Iwanowicza Lamsdorfa, urodzonego w 1745 r. wojskowego. Sama nominacja przebiegła w dosyć specyficznych okolicznościach. Pewnego dnia Paweł, zapewne bez żadnego uprzedzenia, zagaił do Lamsdorfa po niemiecku: Ich habe Sie zum Erzieher meiner Soehne gewaehlt57, kiedy zaś ten, jak się zdaje nieszczególnie ofertą zachwycony, usiłował wymówić się brakiem kompetencji, car dodał: wenn Sie es nicht fuer mich thun wollen, so mueszen Sie es fuer Rusland thun; aber das sage Ich ihnen, das Sie aus meinen Soehnen nicht solche schlingel machen, wie die deutschen Prinzen es $\operatorname{sind}^{58}$. Swoją nową funkcję Lamsdorf objął w roku 1800. Mikołaj miał wówczas cztery lata i do tamtej pory znajdował się pod kobiecą opieką. Swoją matkę widywał rzadko, pieczę zaś nad nim sprawowały dwie guwernantki, panie Lieven i Adlerberg, obie nieprzypadkowo będące żonami niemiecko-bałtyckich oficerów, a także niania, Szkotka Jane Lyon, do której chłopiec był wyjątkowo przywiązany. Elementy militarystyczne towarzyszyły wychowaniu Mikołaja od samego początku. Pierwszy stopień oficerski otrzymał od ojca zaraz po śmierci babki, nie ukończywszy więc nawet pół roku został mianowany pułkownikiem cesarskiej gwardii konnej. Wraz z bratem Michałem od najmłodszych lat bawili się karabinami zabawkami, drewnianymi pałaszami i udającymi

\footnotetext{
56 O śmierci Pawła: N. Ejdelman, op. cit.

${ }^{57}$ N. Dubrowicz, Сборник Императорского Русского исторического общества. Т. 98. Материалы и черты к биографии императора Николая I и к истории его царствования, Petersburg 1896, s. 26.

58 Ibidem.
} 


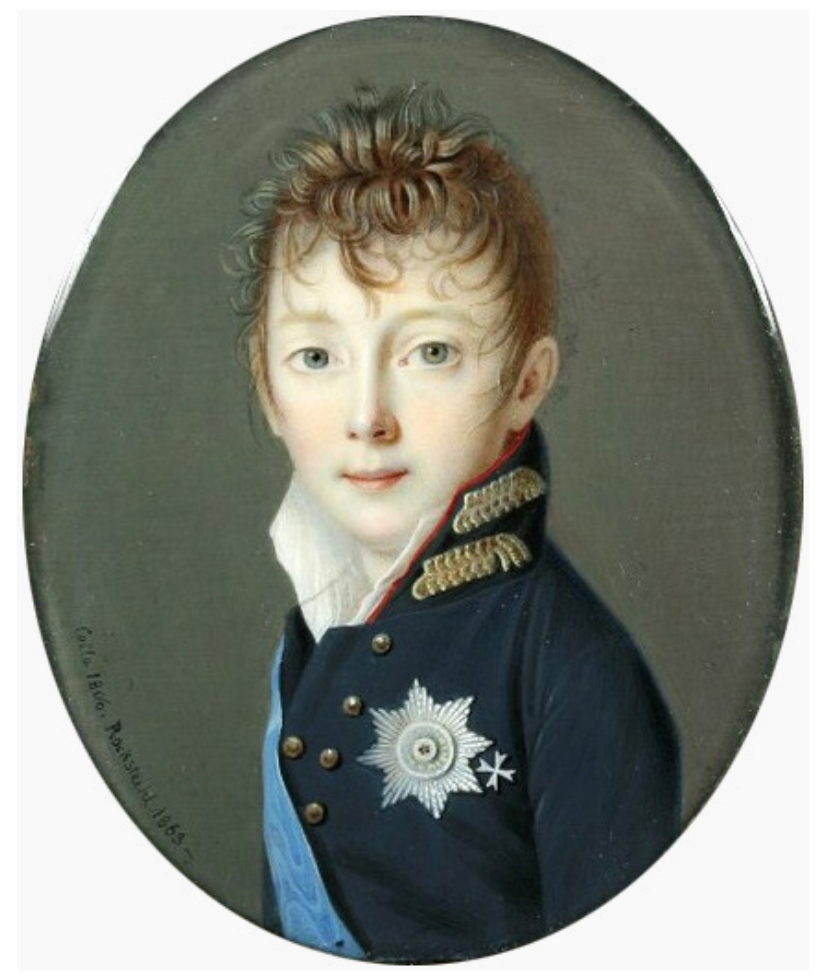

Ryc. 3. Alois Gustav Rochstuhl, Mikołaj I jako dziecko, 1806 (kopia z 1869) (https://commons.wikimedia.org/wiki/

File:Nickolas_I_as_child_by_A.Rockstuhl.jpg)

wojskowe bębenkami. Znamiona wojskowego drylu nosił także sposób, w jaki do swoich niespodziewanych obowiązków podszedł Lamsdorf, człowiek niemający większego pojęcia ani o tym, jak należy wychowywać dzieci, ani też jak wychowywać wielkich książąt, wiedzący jedynie, jak krzewić wśród rekrutów armijną dyscyplinę. Sam Mikołaj później tak oto opisał swojego wychowawcę i jego wpływ: Hrabia Lamsdorf budzit $w$ nas jedynie uczucie strachu; strachu tak wielkiego i takiego przekonania o swojej wszechmocy, że nasza matkę uważaliśmy za mniej ważna osobę. Wyzuwało to nas z wszelkiego synowskiego zaufania do matki, która zreszta rzadko widywaliśmy nie w obecności osób trzecich, a i to jedynie wtedy, kiedy mieliśmy być ukarani ${ }^{59}$.

O matce powiemy jeszcze kilka słów. Ojciec zaś, jak zostało już wspomniane, zdążył nominować wychowawcę swoich najmłodszych synów i niedługo później został zamordowany. Nowy car i starszy brat, Aleksander, nadzór nad Mikołajem i Michałem powierzył całkowicie matce i sam do pewnego momentu niespecjalnie się nimi interesował. Maria Fiodorowna zdecydowała się uszanować wolę zmarłego męża i pozostawiła Lams-

${ }^{59}$ Za: Lincoln W. Bruce, op. cit., s. 50. 
dorfa na stanowisku. Jak się zdaje, odczuwała do niego jakąś sympatię. W. Bruce Lincoln w swojej biografii Mikołaja sugeruje, że sympatia ta wynikać mogła głównie z tego, że Maria, z pochodzenia niemiecka księżniczka, cieszyła się mając w okolicy innego Niemca, w dodatku jak ona niewładającego najbieglej językiem rosyjskim ${ }^{60}$.

Oprócz wychowawcy, kształceniem Mikołaja zajęli się wyznaczeni przez matkę nauczyciele, w większości ludzie o kompetencjach zdecydowanie wyższych, niż te którymi mógł pochwalić się Lamsdorf. Do przedmiotów, jakich uczono Mikołaja, odkąd ukończył siedem lat, należały: ekonomia polityczna, łacina, greka, języki - niemiecki i francuski oraz historia. Później, od roku 1809, dołączyły do nich: logika, prawo i historia prawa, wyższa matematyka, nauki ścisłe i język angielski. Tak szeroki zakres nauczania nie zmieniał jednak zasadniczego faktu - Mikołaj mianowicie nie był ani zbyt pilnym, ani też zdolnym uczniem. Nie trafił również na nauczyciela, który potrafiłby go nauką szczerze zainteresować. W przeciwieństwie do najstarszego brata, który po pierwsze, był pojętny i bystry z natury, po drugie, znalazł w La Harpie doskonałego mentora, po trzecie zaś, wypadał zawsze korzystnie na tle Konstantego, dla Mikołaja lekcje stanowiły głównie utrapienie. Tak naprawdę interesowały go przede wszystkim sprawy wojskowe i niewiele poza tym. Jak się zdaje, żywił również częściowe przynajmniej zainteresowanie historią najnowszą, zwłaszcza rewolucją francuską, kreśloną w czarnych barwach przez nauczyciela historii. W charakterze anegdotycznym zapamiętana została odpowiedź Mikołaja, kiedy na jednej z tych lekcji został spytany, jak ocenia postawę Ludwika XVI. Dziesięcioletni książę odpowiedzieć miał, że francuski król ukazał słabość i zdradził swoje zadanie, oszczędziłby swemu ludowi wielu cierpień, gdyby nie oszczędzit spiskow$c o ́ w^{61}$. Z tego epizodu bardzo łatwo wysnuć paralelę do wydarzeń późniejszych o prawie dwadzieścia lat - kiedy to w obliczu czegoś, co musiało wydać mu się analogiczną sytuacją, Mikołaj, świeżo koronowany na cara, nie pozwolił sobie na podobną słabość i nie oszczędził spiskowców.

Można sobie wyobrazić, że uwagę nastoletniego Mikołaja daleko bardziej od lekcji i nauki zaprzątały działania wojenne. W 1812 r. nie marzył o niczym innym, jak o wzięciu udziału w obronie ojczyzny, pozwolenie jednak na przyłączenie się do armii otrzymał dopiero dwa lata później i wtedy zaś zdążył jedynie na wkroczenie do Paryża, już po kapitulacji. W roku następnym sytuacja się powtórzyła. Kiedy jednak Mikołaj w 1815 roku powrócił do Petersburga po tym drugim wyjeździe, jego życie zaczęło się zmieniać. Skończył już dziewiętnaście lat, jego edukacja miała się ku końcowi, co więcej, w drodze powrotnej zaręczył się oficjalnie z pruską królewną Charlottą. Wszystko to jednak bladło z inną jeszcze zmianą, o której sam Mikołaj wówczas chyba nie mógł mieć jeszcze pojęcia. Prawdopodobnie już wówczas Aleksander I zaczął widzieć w nim swojego potencjalnego następcę. W roku 1816 końca dobiegła edukacja szkolna Mikołaja i rozpoczął się prawdopodobnie najszczęśliwszy okres jego życia, wypełniony sprawami wojskowymi i życiem rodzinnym - małżeństwo Mikołaja i Charlotty, która w Rosji przyjęła imiona Aleksandry Fiodorowny było, jak wskazują na to wszelkie poszlaki, wyjątkowo udane

\footnotetext{
60 Ibidem, s. 50-51.

${ }^{61}$ Ibidem, s. 53.
} 
i dobrane. Okres ten dobiegł końca w grudniu roku 1825, kiedy Mikołaj, wśród okrzyków zbuntowanych oficerów, huku armat i trzasku pękającego pod nogami powstańców lodu Newy wstąpił na cesarski tron. Panował dokładnie trzydzieści lat, a koniec jego rządów i życia nastąpił w okolicznościach nie mniej dramatycznych, niż koronacja podczas przegrywanej właśnie wojny krymskiej.

Zarówno charakter, jak i panowanie cara Mikołaja I nie odznaczały się ambiwalencją, cechującą jego starszego brata. O ile Aleksander I zdawał się mieścić w sobie same sprzeczności, o tyle Mikołaja I cechowała wyraźna i surowa prostolinijność, niepozostawiająca wiele miejsca ani na wahania, ani też wątpliwości. Powszechnie kojarzy się go ze stłumieniem buntu dekabrystów, ze zwyciężeniem powstańców listopadowych, z popowstańczymi represjami, jakie po 1831 r. spadły na Królestwo Kongresowe, z oddziałami, jakie pod dowództwem swojego przyjaciela, księcia warszawskiego Iwana Paskiewicza wysłał do władztwa Habsburgów, aby w 1849 r. pomogły Austrii zwalczyć nieposłusznych Węgrów, wreszcie z wojną krymską i śmiercią poprzedzoną upadkiem Sewastopola. Zarówno jego politykę zewnętrzną, jak i wewnętrzną otoczyła czarna legenda - w pierwszym przypadku związana z wszelką tą działalnością, którą Mikołaj I prowadził w imieniu Świętego Przymierza, w czasach jego rządów mającego już zdecydowanie militarny, nie ideowy charakter, w drugim zaś z tak zwanym systemem mikołajowskim. W całości polityka prowadzona przez Mikołaja I sprawia wrażenie dokładnie tego, czym w istocie była - polityką władcy, który do władzy nie był odpowiednio wychowany i przygotowany, którego główną i największa pasją, a także jedynym światem, który w pełni rozumiał było wojsko i to wojsko w stylu pruskich parad i musztry, nie wojen i strategii. Mikołaj I nie urodził się do bycia cesarzem, kiedy jednak nim został czego zapewne zresztą nie pragnął - usiłował z całą sumiennością jak najlepiej wcielić się w tę rolę i wypełniać ją tak, jak wedle jego wiary i rozeznania najlepiej było dla Rosji. O ile jego starszego brata, Aleksandra I, nazywano Północnym Sfinksem, albo też Talmą Północy - na cześć popularnego wówczas na zachodzie aktora - o tyle Mikołaj I dorobił się dwóch przydomków, z których jednak jeden jest zdecydowanie bardziej pochlebny od drugiego. Nazywano go zatem czasem Żelaznym Carem, czasem zaś - Pałkinem.

Trudno rozstrzygać, co takiego wywarło największy wpływ zarówno na kształtowanie się charakteru Aleksandra I, jak i Mikołaja I, rodzonych braci, których jednak rozdzielały niemal dwie dekady. Co było efektem loterii genetycznej, co - czasów, w których przyszło im żyć i panować, co zaś - wychowania? Naturalnie, nie sposób tego stwierdzić z żadną pewnością, w przypadku jednak tego ostatniego - wychowania wskazać można bardzo znaczące przeciwieństwa, skorelowane w widoczny sposób z przeciwieństwami, jakie dostrzega się w już ukształtowanych osobowościach. O ile więc za wychowanie Aleksandra odpowiadała caryca Katarzyna, władczyni nie bez powodu nazywana oświeconą, o tyle w przypadku Mikołaja odpowiedzialność tę ponosiła głównie matka, caryca Maria Fiodorowna, kierująca się w znacznej mierze wolą zmarłego męża. O ile tym, który odcisnął największy wpływ na Aleksandra jako chłopca był La Harpe, filozof i republikanin, o tyle Mikołaja wychowywał Lamsdorf, wojskowy, wybrany do tego zadania, jak się zdaje, zgoła przypadkiem. Aleksander był wreszcie od 
początku wychowywany na przyszłego władcę, Mikołaj zaś - na żołnierza. Nie sposób właściwie dziwić się temu, który z nich wyrósł na „dziwnego cara”, chwiejnego, pełnego z jednej strony wizji reform, $\mathrm{z}$ drugiej wizji mistycznych, który zaś na kaprala na tronie.

Znamienny jest również fakt, że Mikołaj I dopilnował, aby jego syn i następca otrzymał odpowiednie i wszechstronne przygotowanie do panowania. Głównym wychowawcą carewicza Aleksandra Nikołajewicza został wybitny poeta rosyjski Wasilij Żukowski. Chłopiec zdobył gruntowne wykształcenie, obejmujące cztery języki obce (francuski, niemiecki, angielski i polski), historię, geografię, logikę, filozofię i nauki przyrodnicze, nie zaniedbano również ani spraw wojennych, poza tym zaś od młodości zaznajamiany był z tajnikami spraw państwowych, miał również okazję zwiedzić Europę - był w Austrii, Włoszech, Szwecji, państwach niemieckich i Holandii, a także Anglii, gdzie zadurzyła się w nim młodziutka królowa Wiktoria. Chociaż życie Aleksandra II ${ }^{62}$ zakończyło się nagle i tragicznie, był bez wątpienia jednym z wybitnych władców i reformatorem, który przeprowadził w Rosji wielkie dzieło uwłaszczenia. Można zadać sobie pytanie w jakim stopniu mogło być to zasługą odpowiedniego wychowania i otrzymanej edukacji.

\section{Bibliografia}

\section{Źródła}

Pamiętniki ks. Adama Czartoryskiego i korespondencya jego z cesarzem Aleksandrem I, thum. K. Scipio, Kraków 1904.

Бабушкина азбука великому князю Александру Павловичу (http://dlib.rsl.ru/viewer/01005436372\#?page=6), dostęp 6.07.2017.

Лагарп Ф.Ц., Записки Лагарпа о воспитании в. к. Александра и Константина Павловичей 1786-1789 г2., "Русская старина". Ежемесячное историческое издание. 1870 г. Том I. Санкт-Петербург, 1870, стр. 152-204.

http://www.do1917.info/sites/default/files/user11/pdf/1870rysstarina1\%286\%29.pdf(dostęp 18.08.2017)

\section{Opracowania}

Andrusiewicz A., Aleksander I. Wielki gracz car Rosji - król Polski, Kraków 2015.

Andrusiewicz A., Romanowowie. Imperium i familia, Kraków 2014.

Андреев А. Ю., Император и его учитель: личные и политические аспекты взаимоотношений Александра I и Ф.С. Лагарпа, „Филаретовский альманах”, 8, 2012. С.76-97. http://pstgu. $\mathrm{ru} / \mathrm{scientific/periodicals/almanah/archives/articles/08/(dostęp} \mathrm{20.08.2017)}$

Андреев А. Ю., «Записки» Ф.С. Лагарпа как источник по истории России конца XVIII начала XIX в., „Вестник ПСТГУ”. II. История. История Русской Православной Церкви. 2013. Вып.4 (53). C.7-22 http://periodical.pstgu.ru/ru/pdf/article/2198 (dostęp 18.06.2017)

62 O Aleksandrze II: A. Andrusiewicz, Romanowowie..., s. 427-463 (rozdział „Aleksander II Nikołajewicz. Danse macabre"). 
Андреев А. Ю., Воспитание великих князей Александра и Константина Павловичей глазами Ф.-С. Лагарпа, „Филаретовский альманах” Вып.9, 2013. С. 90-122. http://pstgu.ru/download/1396352146.10andreev.pdf (dostęp 18.08.2017)

Аукштыкальните А. Д., Николай Иванович Салтыков и Фредерик Сезар де Лагарп , Известия Саратовского университета. Серия История, Международные отношения. 2017, т. 17, №1, стр. 28-34. https://cyberleninka.ru/article/v/nikolay-ivanovich-saltykov-i-frederik-sezar-de-lagarp (dostęp 18.08.2017).

Bortnowski W., Wielki Ksiązę Konstanty i Joanna Grudzińska, Łódź 1961.

Bridel G., Le gouverneur d'un prince: Frederic Cesar de Laharpe et Alexandre I. de Russie. D'apres les manuserits inedits de F. C. de Laharpe et les sources russes les plus recentes, Lausanne 1902.

Dubrowicz N., Сборник Императорского Русского исторического общества. Т. 98. Материалы и черты к биографии императора Николая I и к истории его царствования, Petersburg 1896.

Ejdelman Natan, Paweł I, czyli śmierć tyrana, tłum. W. i R. Śliwowscy, Warszawa 1990.

Karnowicz E.P., Wielki Książe Konstanty. Zarys biograficzny, Warszawa 1900.

King S., Wiedeń 1814. Jak pogromcy Napoleona, bawiąc się, ustalili ksztatt Europy, t1. N. Radomski, Poznań 2009.

Lincoln W. B., Mikołaj I, thum. H. Krzeczkowski, Warszawa 1988.

Montefiore S.S., Katarzyna Wielka i Potiomkin, tł. K. Bażyńska-Chojnacka, P. Chojnacki, W. Jeżewski, Warszawa 2013.

Zamoyski A., Święte szaleństwo. Romantycy, patrioci, rewolucjoniści 1776-1871, thum. M. Ronikier, Kraków 2015, s. 274-275. 
